\title{
Nitrogen excretion and changes of hemocyanin, protein and free amino acid levels in the hemolymph of Penaeus monodon exposed to different concentrations of ambient ammonia-N at different salinity levels
}

\author{
Jiann-Chu Chen, Chung-Tin Chen, Sha-Yen Cheng \\ Department of Aquaculture, National Taiwan Ocean University, Keelung, Taiwan, 20224, Republic of China
}

\begin{abstract}
Penaeus monodon $(22.064 \pm 2.263 \mathrm{~g})$ were exposed individually at 10,20 and $30 \%$ salinity to 0 (control), 1, 5, 10 and $20 \mathrm{mg} \mathrm{l}^{-1}$ ammonia- $\mathrm{N}$ for $24 \mathrm{~h}$. Changes in hemocyanin, protein and free amino acid levels, and whole shrimp ammonia- $\mathrm{N}$ excretion, urea- $\mathrm{N}$ excretion and dissolved organic $\mathrm{N}$ (DON) excretion were determined. Ammonia- $N$ excretion decreased with increased salinity and with increased ambient ammonia-N. Ammonia- $\mathrm{N}$ accounted for $56.87,70.43$ and $78.13 \%$ of total nitrogen excreted by $P$. monodon in 30,20 and $10 \%$, respectively. DON increased to $67.26,78.79$ and $86.1 \%$ of total nitrogen excreted by the shrimp exposed to $20 \mathrm{mg} \mathrm{l}^{-1}$ ammonia- $\mathrm{N}$ in 30,20 and $10 \%$, respectively. Net ammonia-N uptake occurred as shrimp were exposed to ambient ammonia-N greater than $5 \mathrm{mg} \mathrm{l^{-1 }}$ at all salinity levels tested. Hemocyanin and protein levels decreased, whereas hemolymph ammonia, urea, total free amino acid levels and taurine level increased, with increased ambient ammonia-N. Following exposure to ambient ammonia-N, P. monodon changed its excretory pattern, accumulation of hemolymph ammonia, and catabolism of hemocyanin and protein to balance osmoregulation.
\end{abstract}

KEY WORDS: Penaeus monodon - Nitrogen excretion - Hemocyanin - Protein - Free amino acid . Ammonia $\cdot$ Urea $\cdot$ Accumulation $\cdot$ Salinity $\cdot$ Metabolism

\section{INTRODUCTION}

The tiger shrimp Penaeus monodon is widely distributed throughout the Indo-Pacific region. This species is of commercial importance. It is an omnivore with a rapid growth and tolerates a wide range of salinities and temperatures. The level of salinity suitable for growth of P. monodon is in the range 10 to $30 \%$ (Liao \& Murai 1986). Effects of salinity on oxygen consumption and ammonia- $\mathrm{N}$ (un-ionized plus ionized ammonia as nitrogen) excretion were reported by Lei et al. (1989).

Ammonia, the end product of protein catabolism, accounts for more than half of the nitrogenous waste released by decapod crustaceans (Regnault 1987). Most ammonia is excreted via the gill epithelium, through diffusion of $\mathrm{NH}_{3}$ (un-ionized ammonia) and/or $\mathrm{NH}_{4}{ }^{+}$(ionized ammonia), and $\mathrm{Na}^{+} / \mathrm{NH}_{4}{ }^{+}$exchanges (Kormanik \& Cameron 1981, Pequeux \& Gilles 1981, Pressley et al. 1981).

Elevated environmental ammonia has been reported to affect growth and molting (Chen \& Kou 1992), oxygen consumption and ammonia- $\mathrm{N}$ excretion (Chen \& Lin 1992), and $\mathrm{Na}^{+}, \mathrm{K}^{+}$-ATPase activities of penaeids (Chen \& Nan 1992). Ammonia has also been reported to affect osmoregulatory capacity and $\mathrm{Na}^{+}$concentration in the hemolymph of American lobster Homarus americanus (Young-Lai et al. 1991).

The respiratory pigment hemocyanin represents 60 to $95 \%$ of the total protein in the hemolymph of crustaceans (Djangmah 1970, Jeuniaux 1971). 
Changes in osmotic concentration are considered to induce drastic changes in protein and amino acid composition in the tissues. Hemocyanin was reported to increase in shore crab Carcinus maenas under hypoosmotic stress (Boone \& Schoffeniels 1979). Hemolymph protein was affected by salinity in Chinese crab Eriocheir sinensis (Gilles 1977) and by ambient ammonia in fleshy prawn Penaeus chinensis (Chen et al. 1993).

The concentration of FAA (free amino acid) in crustaceans is generally several times higher than that in vertebrates. Nitrogen metabolism and the role of FAA in the regulation of intracellular osmolarity and volume regulation have been widely studied and reviewed by Claybrook (1983) and Gilles \& Pequeux (1983). Several studies have reported an increase of ammonia excretion and a spontaneous decrease of tissue FAA when crustaceans are exposed to hypo-osmotic conditions (Haberfield et al. 1975, Mangum et al. 1976). Effects of salinity on FAA composition have been examined for Kuruma shrimp Penaeus japonicus by Dalla Via (1986) and for P. monodon by Fang et al. (1992). However, nothing is known of the effects of ammonia on hemocyanin and FAA levels and electrolytes in the hemolymph of penaeids.

Using Penaeus chinensis juveniles, Chen \& Lin (1992) reported that ammonia- $N$ excretion increased when increased ambient ammonia- $\mathrm{N}$ was in the range 0.036 to $0.942 \mathrm{mg} \mathrm{l}^{-1}$, and decreased when increased ambient ammonia- $\mathrm{N}$ was in the range 0.942 to $9.921 \mathrm{mg} \mathrm{l}^{-1}$, in $30 \%$ seawater. We hypothesize that shrimp in high concentrations of ambient ammonia- $N$ may disturb their nitrogen metabolism and shift to urea excretion, as do some teleosts (Olson \& Fromm 1971). The purpose of the present study was to determine hemocyanin, hemolymph protein and FAA levels, and ammonia- $\mathrm{N}$, urea- $\mathrm{N}$ and dissolved organic $\mathrm{N}$ excretions, of $P$. monodon exposed to different concentrations of ambient ammonia- $\mathrm{N}$ at different salinities.

\section{MATERIALS AND METHODS}

Penaeus monodon obtained from a shrimp farm in lilan, Taiwan, were kept in 3 circular tanks with seawater at $30 \%$ for $1 \mathrm{wk}$, and then acclimated to 30,20 and $10 \%$ for another $1 \mathrm{wk}$ in our laboratory. The salinity was adjusted by a decrease of 2 to $3 \%$ per day with fresh water until salinities of 30,20 and $10 \%$ were reached. Shrimp were fed daily with commercial shrimp food (39\% crude protein) manufactured by Tairoun Products Co. (Taipei, Taiwan). They were starved for $2 \mathrm{~d}$ prior to the experiment.

Ammonia test solutions consisting of concentrations of $O$ (control), 1, 5, 10 and $20 \mathrm{mg} \mathrm{l}^{-1}$ ammonia- $\mathrm{N}$ were prepared with 30,20 and $10 \%$ according to the procedure reported previously (Chen \& Nan 1992). The concentrations of ammonia- $\mathrm{N}$ are sublethal, based on a short-term toxicity test which showed no mortality of Penaeus monodon $\left(4.87 \pm 1.40 \mathrm{~g}\right.$ ) exposed to $40 \mathrm{mg} \mathrm{l}^{-1}$ ammonia- $\mathrm{N}$ in $20 \%$ after 24 h (Chen et al. 1990).

Shrimp were taken from the holding tank and transferred individually to a $20 \mathrm{l}$ circular plastic tank containing $10 \mathrm{l}$ of each test solution. Individual tanks were aerated by means of an air blower with an aeration stone attached. After $24 \mathrm{~h}$ exposure, shrimp were examined for molt stage by examining the uropoda, in which partial retraction of the epidermis can be distinguished (Wassenberg \& Hill 1984). Only shrimp in the intermolt stage were used for the study. There were 15 treatments, each treatment being conducted with 5 individuals. The total number of shrimp used was 75 .

Shrimp used ranged from 19.43 to $25.68 \mathrm{~g}$ with an average weight of $22.06 \pm 2.26 \mathrm{~g}$ (mean $\pm \mathrm{SD}$ ). Each tank was covered with a plastic cap to prevent escape. The experiment started at 09:00 h and lasted for $24 \mathrm{~h}$ under a photoperiod of $12 \mathrm{~h}$ light : $12 \mathrm{~h}$ dark with mea-

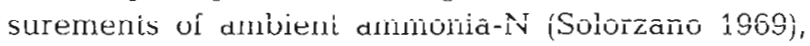
urea-N (McCarthy 1970), total dissolved nitrogen (Solorzano \& Sharp 1980), nitrite-N (Bendschneider \& Robinson 1952) and nitrate-N (Wood et al. 1967) at the beginning and end of the experiment. Analyses of these water parameters were finished in $3 \mathrm{~d}$. Dissolved organic $\mathrm{N}$ (DON) was calculated based on the difference between total dissolved nitrogen, urea- $N$, ammonia- $N$, nitrite- $N$ and nitrate- $N$. The differences in concentrations of ammonia- $N$, urea- $N, D O N$, nitrite- $N$ and nitrate- $N$ of each test solution at the end and the beginning of the experiment were converted to ammonia-N excretion, urea- $\mathrm{N}$ excretion, DON excretion, nitrite- $N$ excretion and nitrate- $N$ excretion $\left(\mu g g^{-1}\right.$ $\mathrm{h}^{-1}$ ). During the experimental period, mean water temperature, dissolved oxygen and $\mathrm{pH}$ (mean $\pm \mathrm{SD}$ ) were $25.5 \pm 0.5^{\circ} \mathrm{C}, 7.34 \pm 0.16 \mathrm{mg} \mathrm{l}^{-1}$ and $8.12 \pm 0.03$, respectively.

After $24 \mathrm{~h}$ exposure to each test solution, shrimp were sampled for hemolymph hemocyanin, protein and FAA levels. All the experiments were completed in $15 \mathrm{~d}$. Sampling and preparation of hemolymph for analyses of hemocyanin and protein was undertaken as follows. Hemolymph $(100 \mu \mathrm{l})$ was taken by carefully inserting a $1.0 \mathrm{ml}$ disposable syringe, fitted with a 22 gauge, $0.50 \times 25 \mathrm{~mm}$ needle which was rinsed with buffer $(0.10 \mathrm{M}$ sodium citrate, $0.25 \mathrm{M}$ sodium chloride, pH 7.5), into the abdomen. The hemolymph samples were removed individually using the syringe from the pericardial cavity through the intersegmental membrane between the cephalothorax and the abdominal segment. The sampled hemolymph was placed in a $1.5 \mathrm{ml}$ Eppendorf tube containing $900 \mu \mathrm{l}$ distilled 
water, and then mixed immediately with type 37600 mixer (Barnstead/Thermolyne Company, Dubuque, IA, USA). Using this method, the hemolymph did not clot and was also dissolved equally by the addition of water. Since the reported concentrations of hemolymph protein of penaeids range from 62 to $103 \mathrm{mg}$ $\mathrm{ml}^{-1}$ (Bursey \& Lane 1971, Balazs et al. 1974, Chen \& Cheng 1993, Chen et al. 1993), dilution of hemolymph sample is necessary. This dilution technique has been used successfully for determinations of hemocyanin and protein in a number of decapod crustaceans (Senkbeil \& Wriston 1981, Hagerman 1983, 1986, Ferraris et al. 1986, Hagerman \& Baden 1988, Chen \& Cheng 1993, Chen et al. 1993). To check if dilution affected the measured concentrations of hemocyanin and protein, the hemolymph samples were allowed to coagulate at $4{ }^{\circ} \mathrm{C}$, and then centrifuged at $10000 \times g$ for $10 \mathrm{~min}$. Concentrations of hemocyanin and protein were examined using (1) hemolymph diluted with distilled water, (2) hemolymph diluted with buffer and (3) serum. No significant difference was found among the 3 treatments. Measurements of hemocyanin and protein were therefore carried out using diluted hemolymph with distilled water.

Hemolymph protein was determined with a Bio-Rad Protein Assay Kit No. 500-0006 (Bio-Rad Laboratories, Richmond, CA, USA) using bovine serum albumin (molecular weight 66000 daltons) as a standard according to a method derived from Bradford (1976). For measurement of hemocyanin, $100 \mu$ l hemolymph was immediately diluted with $900 \mu$ distilled water in a $10 \mathrm{~mm}$ quartz cuvette and the absorbance was measured at $335 \mathrm{~nm}$ using a Hitachi U-2000 spectrophotometer (Hitachi Ltd, Tokyo, Japan). The hemocyanin concentration was calculated using an extinction coefficient $\left(\mathrm{E}_{1 \mathrm{~cm}}^{\mathrm{mM}}\right)$ of 17.26 , calculated from $E_{1 \mathrm{~cm}}^{1 \%}=2.83$ (Nickerson \& Van Holde 1971) on the basis of a functional subunit of 74000 (Antonini \& Brunori 1974). The ratio of hemocyanin to protein was calculated by dividing the concentration of hemocyanin ( $\mathrm{mmol}^{-1}$ ) by that of protein ( $\mathrm{mmol} \mathrm{l}^{-1}$ converted from $\mathrm{mg} \mathrm{ml}^{-1}$ to $\mathrm{mmol}$ $1^{-1}$ by dividing by 66 ).

For measurement of FAA level, $0.5 \mathrm{ml}$ hemolymph was sampled from each individual exposed to each test solution. An equal volume of $5 \%$ sulfosalicylic acid was added to precipitate protein, and centrifuged at $13300 \times g$ for 15 min with a Model Sigma 4 K10 centrifuge (Sigma Laborzentrifugen $\mathrm{GmbH}$, Osterode, Germany). A volume of $200 \mu \mathrm{l}$ of supernatant was diluted with $1 \mathrm{ml}$ of $0.02 \mathrm{~N} \mathrm{HCl}$, then $80 \mu \mathrm{l}$ of the mixture was injected into a Model L-8500 High Speed Amino Acid Analyzer connected with a Model D-2850 Chromato-Integrater (Hitachi Ltd, Tokyo, Japan) for analysis of FAA. Ammonia and urea concentrations were recorded at the same time by the analyzer.
Two-way analysis of variance was used for statistical analysis (Steel \& Torrie 1980). The linear relationships among ambient ammonia- $\mathrm{N}$, salinity, and the variables ammonia- $\mathrm{N}$ excretion, urea- $\mathrm{N}$ excretion, DON excretion, nitrite- $\mathrm{N}$ excretion, nitrate- $\mathrm{N}$ excretion, hemocyanin, hemolymph protein, the ratio of hemocyanin/protein, FAA, hemolymph ammonia and hemolymph urea were tested using the General Linear Model Procedure and Regression Procedure, version 6.03 of the SAS (Statistical Analysis System) computer software (SAS 1988). All statistical significance tests were at the $p<0.05$ level.

\section{RESULTS}

In the control solution (0) at 10,20 and $30 \%$, ammonia- $\mathrm{N}$ excretion varied from 10.7 to $14.8,6.1$ to 10.3 and 4.5 to $6.7 \mu \mathrm{g} \mathrm{g}^{-1} \mathrm{~h}^{-1}$, respectively, with averages of 12.5, 8.8 and $5.5 \mu \mathrm{g} \mathrm{g}^{-1} \mathrm{~h}^{-1}$. In comparison, for shrimp exposed to $5 \mathrm{mg} \mathrm{l}^{-1}$ ammonia- $\mathrm{N}$ or higher at all salinity levels, ammonia- $N$ excretion was inhibited and net ammonia- $\mathrm{N}$ uptake occurred. Ammonia- $\mathrm{N}$ uptake of shrimp increased when increased ambient ammonia- $\mathrm{N}$ was in the range 5 to $20 \mathrm{mg} \mathrm{l}^{-1}$ at all salinity levels tested (Fig. 1A).

Analysis of variance indicated that there was a significant effect of ambient ammonia- $\mathrm{N}$ and salinity on ammonia- $\mathrm{N}$ excretion, and that there was a significant interaction between the effects of ambient ammonia- $\mathrm{N}$ and salinity on ammonia- $\mathrm{N}$ excretion. The relationship between ammonia- $\mathrm{N}$ excretion (ANE), and ambient ammonia- $\mathrm{N}(C)$, salinity $(S)$ and the interaction between ambient ammonia- $\mathrm{N}$ and salinity $(C S)$ is as follows: $A N E=5.6049-0.9145 C-0.1311 S-0.0013 C S$ $\left(\mathrm{R}^{2}=0.66\right)$

In the control solution at 10 and $20 \%$, urea- $\mathrm{N}$ excretion of shrimp varied from 0.09 to 0.13 and 0.18 to $0.30 \mathrm{\mu g} \mathrm{g}^{-1} \mathrm{~h}^{-1}$, respectively, with averages of 0.12 and $0.27 \mathrm{\mu g} \mathrm{g}^{-1} \mathrm{~h}^{-1}$. Urea- $\mathrm{N}$ excretion of shrimp increased with increased concentrations of ambient ammonia-N at all 3 salinity levels. Urea-N excretion of shrimp exposed to $20 \mathrm{mg} \mathrm{l}^{-1}$ ammonia-N at $30 \%$ was $23.2 \mu \mathrm{g} \mathrm{g}^{-1}$ $\mathrm{h}^{-1}$, significantly higher than that of shrimp exposed to the same ambient ammonia- $\mathrm{N}$ at 10 and $20 \%$ (Fig. 1B).

Analysis of variance indicated that there was a significant effect of ambient ammonia- $\mathrm{N}$ and salinity on urea- $\mathrm{N}$ excretion, and that there was a significant interaction between the effects of ambient ammonia- $\mathrm{N}$ and salinity on urea- $\mathrm{N}$ excretion. The relationship between urea- $N$ excretion (UNE) and $C, S$ and $C S$ is as follows: $U N E=-1.0531+0.6651 C+0.0612 S+$ $0.0135 C S\left(R^{2}=0.89\right)$.

Dissolved organic $\mathrm{N}$ excretion increased when increased ambient ammonia- $\mathrm{N}$ was in the range 0 to 

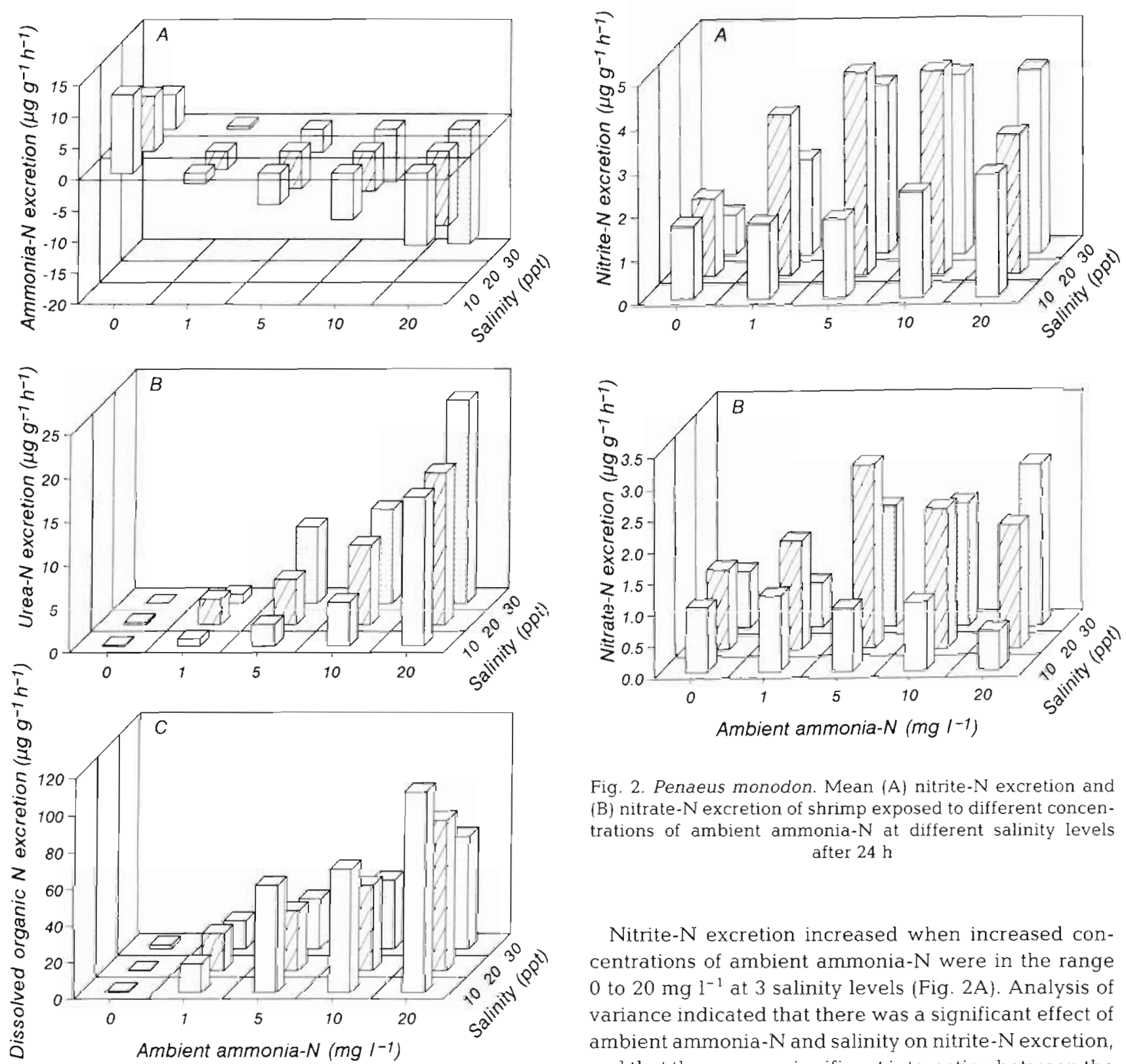

Fig. 2. Penaeus monodon. Mean (A) nitrite-N excretion and (B) nitrate- $\mathrm{N}$ excretion of shrimp exposed to different concentrations of ambient ammonia- $\mathrm{N}$ at different salinity levels after $24 \mathrm{~h}$

Fig. 1. Penaeus monodon. Mean (A) ammonia-N excretion, (B) urea-N excretion and (C) dissolved organic $N$ excretion of shrimp exposed to different concentrations of ambient ammonia- $\mathrm{N}$ at different salinity levels after $24 \mathrm{~h}$

$20 \mathrm{mg} \mathrm{l}^{-1}$ at 3 salinity levels (Fig. 1C). Analysis of variance indicated that there was a significant effect of ambient ammonia- $\mathrm{N}$ and salinity on DON excretion, and that there was a significant interaction between the effects of ambient ammonia- $N$ and salinity on DON excretion. The relationship between DON excretion (DONE) and $C, S$ and $C S$ is as follows: $D O N E=15.7667+6.0606 C-0.1696 S-0.1195 C S\left(R^{2}\right.$ $=0.83$ ).

Nitrite- $\mathrm{N}$ excretion increased when increased concentrations of ambient ammonia- $N$ were in the range 0 to $20 \mathrm{mg} \mathrm{l}^{-1}$ at 3 salinity levels (Fig. 2A). Analysis of variance indicated that there was a significant effect of ambient ammonia- $\mathrm{N}$ and salinity on nitrite- $\mathrm{N}$ excretion, and that there was a significant interaction between the effects of ambient ammonia- $\mathrm{N}$ and salinity on nitrite- $\mathrm{N}$ excretion. The relationship between nitrite- $N$ excretion (NINE) and $C, S$ and $C S$ is as follows: NINE $=1.9516-$ $0.0034 C+0.0215 S+0.0037 C S\left(R^{2}=0.24\right)$.

No significant effect of ambient ammonia- $N$ on nitrate-N excretion was found, nor was there a significant interaction between the effects of ambient ammonia- $\mathrm{N}$ and salinity on nitrate- $\mathrm{N}$ excretion (Fig. 2B).

Percentages of ammonia- $\mathrm{N}$ excretion, urea-N excretion, DON excretion, nitrite- $\mathrm{N}$ excretion and nitrate- $\mathrm{N}$ excretion are given in Table 1 . It indicates that ammonia- $N$ excretion represented $56.87,70.43$ and $78.13 \%$ of total nitrogen excreted by Penaeus monodon in 30,20 and $10 \%$, respectively. Urea- $N$ excretion and DON excretion increased with increased ambient 
ammonia- $\mathrm{N}$. In $20 \mathrm{mg} \mathrm{l^{-1 }}$ ammonia- $\mathrm{N}$, urea- $\mathrm{N}$ constituted $25.38,16.74$ and $11.15 \%$ of total nitrogen excreted, whereas DON constituted 67.26, 78.79 and $86.15 \%$ of total nitrogen excreted by $P$. monodon in 30 , 20 and $10 \%$, respectively.

Hemocyanin (Fig. 3A) and protein (Fig. 3B) in the hemolymph of shrimp decreased with increased ambient ammonia- $\mathrm{N}$ at all salinities. Analysis of variance indicated that there was a significant effect of ambient ammonia- $\mathrm{N}$ and salinity on the hemocyanin and hemolymph protein, and that there was a significant interaction between the effects of ambient ammonia- $\mathrm{N}$ and salinity on hemocyanin. However no significant interaction between the effects of ambient ammonia- $N$ and salinity on hemolymph protein was observed. The relationships between hemocyanin $(H C)$ and $C, S$ and $C S$, and between hemolymph protein (HP) and $C$ and $S$, are as follows: $H C=1.0247-0.0194 C-0.0039 S+$ $0.0003 C S\left(R^{2}=0.56\right), H P=125.0963-0.8590 C-$ $1.2124 S\left(R^{2}=0.38\right)$.

The ratio of hemocyanin to protein in the hemolymph of shrimp decreased with increasing ambient ammonia-N at 3 salinity levels (Fig. 3C). Analysis of variance indicated that there was a significant effect of ambient ammonia- $\mathrm{N}$ and salinity on the hemocyanin/protein ratio. However, no significant interaction between the effects of ambient ammonia- $\mathrm{N}$ and salinity on the hemocyanin/protein ratio was observed. The relationship between the hemocyanin/protein ratio (RHP) and $C$ and $S$ is as follows: $R H P=50.1311-0.4062 C+0.6820 S\left(\mathrm{R}^{2}=0.47\right)$.

Shrimp exposed to ambient ammonia-N at $1 \mathrm{mg} \mathrm{l}^{-1}$ decreased levels of hemocyanin more than protein.
Hemocyanin of shrimp exposed to $20 \mathrm{mg} \mathrm{l}^{-1}$ at 10,20 and $30 \%$ was $63.2,75.7$ and $76.2 \%$ of that of control shrimp, while hemolymph protein of shrimp exposed to $20 \mathrm{mg} \mathrm{l}^{-1}$ at 10,20 and $30 \%$ was $78.7,84.1$ and $88.3 \%$ of that of control shrimp.

Total free amino acid (TFAA) level increased with increased salinity level and ambient ammonia- $N$ (Fig. 4A). Analysis of variance indicated that there was a significant effect of ambient ammonia and salinity on the TFAA. However, there was no significant interaction between the effects of ammonia- $\mathrm{N}$ and salinity on TFAA in the hemolymph. The relationship between TFAA, and $C$ and $S$ is as follows: TFAA $=3665.3688+$ $79.9472 C+54.2113 S\left(R^{2}=0.46\right)$.

Analysis of variance indicated that there was a significant effect of salinity on essential free amino acid (EFAA). However, no significant effect of ambient ammonia-N on EFAA was observed, nor was any significant interaction observed between the effects of ammonia-N and salinity on EFAA in the hemolymph of shrimp (Fig. 4B).

No significant effect of ambient ammonia- $N$ and salinity on nonessential free amino acid (NFAA) was observed, nor was any significant interaction observed between the effects of ambient ammonia- $N$ and salinity on NFAA in the hemolymph of shrimp (Fig. 4C)

Analysis of variance indicated that there was a significant effect of ambient ammonia- $\mathrm{N}$ and salinity on hemolymph ammonia, and that there was a significant interaction between the effects of ambient ammonia- $\mathrm{N}$ and salinity on hemolymph ammonia (Fig. 5A). The relationship between hemolymph ammonia $(H A)$ and

Table 1. Penaeus monodon. Percentage of nitrogenous excretion of shrimp exposed to different concentrations of ambient ammonia-N at 3 salinity levels for $24 \mathrm{~h}$. ANE: ammonia-N excretion; NINE: nitrite-N excretion; NANE: nitrate-N excretion; UNE: Urea$\mathrm{N}$ excretion; DONE: dissolved organic N excretion

\begin{tabular}{|c|c|c|c|c|c|c|}
\hline \multirow[t]{2}{*}{ Salinity $(\%)$} & \multirow[t]{2}{*}{ Nitrogen excretion } & \multicolumn{5}{|c|}{ Nitrogen excretion (\%) at ambient ammonia- $\mathrm{N}$ concentration of: } \\
\hline & & $0 \mathrm{mg} \mathrm{l}^{-1}$ & $1 \mathrm{mg} \mathrm{l^{-1 }}$ & 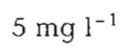 & $10 \mathrm{mg} \mathrm{l}^{-1}$ & $20 \mathrm{mg} \mathrm{l}^{-1}$ \\
\hline \multirow[t]{5}{*}{30} & ANE & 56.87 & 2.47 & - & - & - \\
\hline & NINE & 9.59 & 11.01 & 9.21 & 7.45 & 4.55 \\
\hline & NANE & 9.23 & 3.59 & 4.59 & 3.61 & 2.81 \\
\hline & UNE & 2.13 & 5.19 & 20.92 & 19.78 & 25.38 \\
\hline & DONE & 22.18 & 77.74 & 65.28 & 69.16 & 67.26 \\
\hline \multirow[t]{5}{*}{20} & $A N E$ & 70.43 & - & - & - & - \\
\hline & NINE & 14.49 & 12.78 & 10.12 & 7.40 & 3.05 \\
\hline & NANE & 10.31 & 6.01 & 6.39 & 3.55 & 1.42 \\
\hline & $U N E$ & 2.19 & 10.24 & 11.44 & 14.59 & 16.74 \\
\hline & DONE & 2.58 & 70.97 & 72.05 & 74.46 & 78.79 \\
\hline \multirow[t]{5}{*}{10} & ANE & 78.13 & - & - & - & - \\
\hline & NINE & 10.34 & 8.80 & 2.83 & 3.17 & 2.21 \\
\hline & NANE & 6.41 & 6.19 & 1.56 & 1.44 & 0.49 \\
\hline & UNE & 0.72 & 4.31 & 3.98 & 6.69 & 11.15 \\
\hline & DONE & 4.40 & 80.70 & 91.63 & 88.70 & 86.15 \\
\hline
\end{tabular}



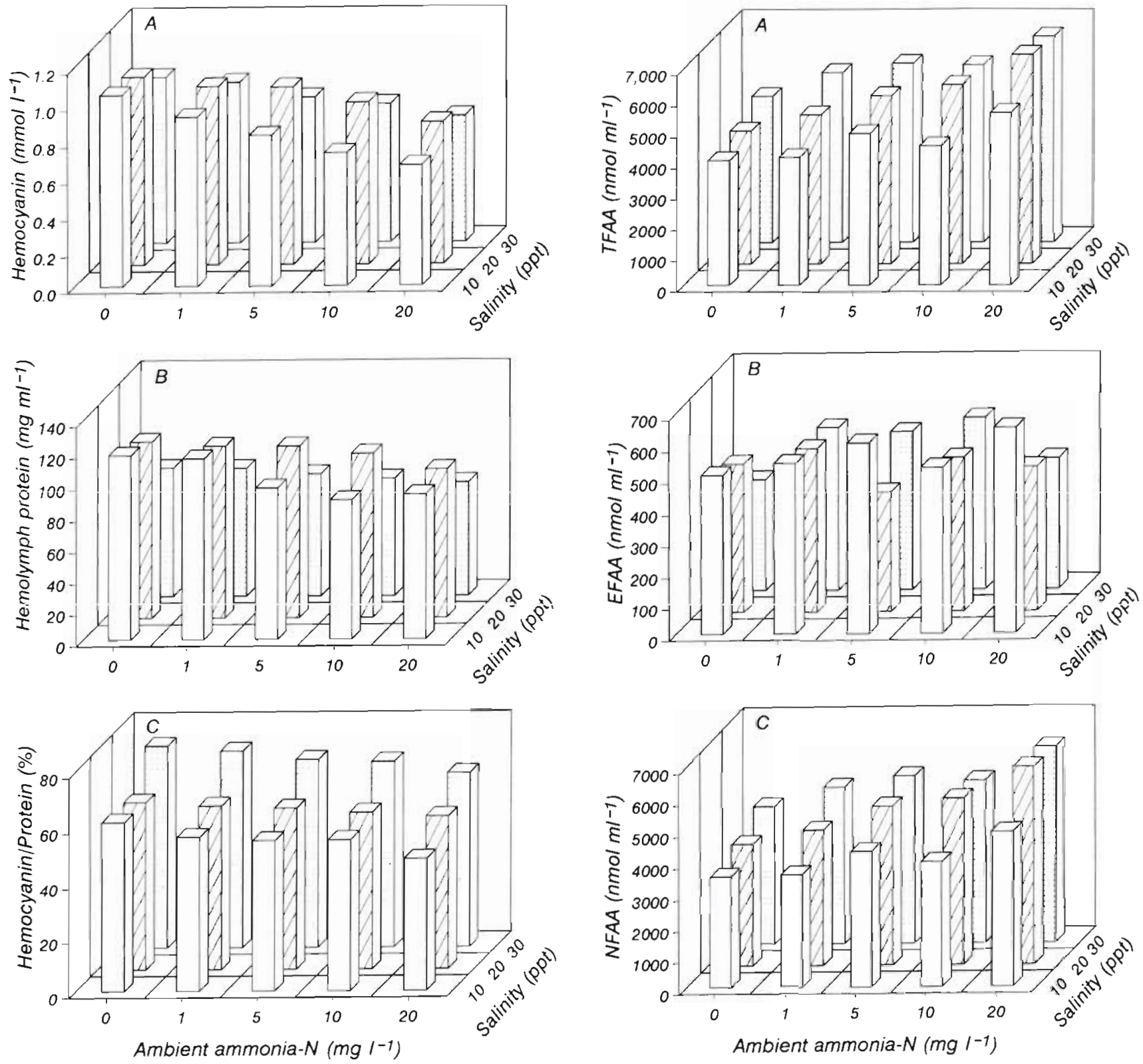

Fig. 3. Penaeus monodon. Mean (A) hemocyanin, (B) hemolymph protein and (C) the ratio of hemocyanin/protein of shrimp exposed to different concentrations of ambient ammonia- $\mathrm{N}$ at different salinity levels after $24 \mathrm{~h}$

C, $S$ and $C S$ is as follows: $H A=390.6486+6.7646 C-$ $0.8274 S+1.5948 C S\left(R^{2}=0.69\right)$.

Analysis of variance indicated that there was a significant effect of ambient ammonia- $\mathrm{N}$ and salinity on hemolymph urea. However, no significant interaction between the effects of ambient ammonia- $\mathrm{N}$ and salinity on hemolymph urea was observed. The relationship between hemolymph urea $(H U)$ and $C$ and $S$ is as follows: $H U=-147.2772+19.6697 \mathrm{C}+58.8944 \mathrm{~S}$ $\left(\mathrm{R}^{2}=0.49\right)$.

Fig. 4. Penaeus monodon. Mean (A) total free amino acid, (B) essential free amino acid and (C) nonessential free amino acid in the hemolymph of shrimp exposed to different concentrations of ambient ammonia- $\mathrm{N}$ at different salinity levels after $24 \mathrm{~h}$

\section{DISCUSSION}

Concentration of ammonia in an organism's blood, in which ammonia enters via diffusion from ambient water or metabolic production, is a principal feature for assessing physiological function. In crustaceans, the normal blood ammonia level varies from 0.033 to $0.95 \mathrm{mmol} \mathrm{l}^{-1}$ among species (Binns 1969, Mangum et al. 1976, Harris \& Andrews 1985, Hagerman et al. 1990, Chen \& Kou 1991). The present study showed 

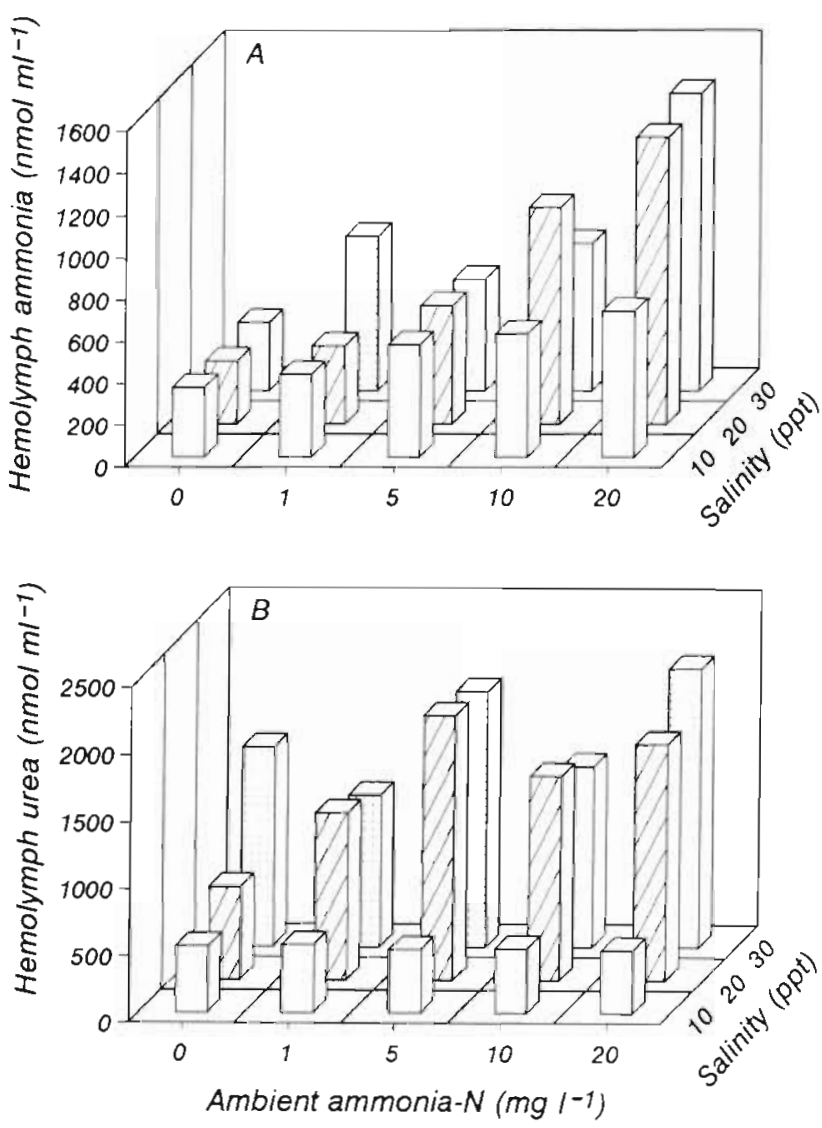

Fig. 5. Penaeus monodon. Mean (A) ammonia and (B) urea in the hemolymph of shrimp exposed to different concentrations of ammonia- $N$ at different salinity levels after $24 \mathrm{~h}$

hemolymph ammonia levels of $0.336,0.302$ and $0.328 \mathrm{mmol} \mathrm{l}^{-1}$ in 10,20 and $30 \%$, respectively.

Effects of salinity on ammonia excretion have been documented for Carcinus maenas (Haberfield et al. 1975), for Penaeus chinensis (Chen \& Lin 1992), for $P$. japonicus (Spaargaren et al. 1982, Chen \& Lai 1993), for $P$. monodon (Lei et al. 1989) and for spot shrimp Pandalus palatyceros (Quarmby 1985). Increase of ammonia-N excretion occurred in decreased salinity from 30 to $10 \%$ in both $P$. chinensis and $P$. japonicus (Chen \& Lin 1992, Chen \& Lai 1993).

Three pathways account for the loss of metabolic ammonia in fish and crustaceans: (1) diffusion of $\mathrm{NH}_{3}$ from blood to water, (2) exchange transport of $\mathrm{NH}_{4}$ with $\mathrm{Na}^{+}$and (3) conversion to a less toxic compound like urea (Campbell 1973). Diffusion of $\mathrm{NH}_{3}$ is the principal route of excretion because blood concentrations are usually much higher than the ambient water concentration (Kinne 1976).

Regnault (1987) reported that the ammonia excretion of common shrimp Crangon crangon was not influenced by ammonia- $\mathrm{N}$ concentrations ranging from 28 to $1218 \mathrm{mg} \mathrm{l}^{-1}$. The present study indicated that ammonia- $\mathrm{N}$ excretion of Penaeus monodon increased as ambient ammonia- $\mathrm{N}$ increased in the range 0 to $5 \mathrm{mg} \mathrm{l}^{-1}$, but decreased in the range 5 to $20 \mathrm{mg} \mathrm{l}^{-1}$, and that net ammonia- $\mathrm{N}$ uptake occurred at ambient ammonia- $\mathrm{N}$ greater than $5 \mathrm{mg} \mathrm{l}^{-1}$ after $24 \mathrm{~h}$ exposure. Similar results were obtained by Chen \& Lin (1992) for $P$. chinensis juveniles $(0.54 \pm 0.11 \mathrm{~g})$ which displayed a net ammonia- $N$ uptake at ambient ammonia-N of $5.087 \mathrm{mg} \mathrm{l}^{-1}$. Studying $P$. japonicus $(13.91 \pm$ 0.65 g), Chen \& Kou (1991) reported that shrimp exposed to increased concentrations of ambient ammonia-N had significantly greater levels of hemolymph ammonia. They suggested that once $\mathrm{NH}_{3}$ diffuses from water into the hemolymph, the relative proportions of $\mathrm{NH}_{3}$ and $\mathrm{NH}_{4}{ }^{+}$constituting the ambient ammonia-N readjust and thus $\mathrm{NH}_{3}$ diffuses continuously in the hemolymph.

Chen et al. (1993) reported that hemolymph levels of ammonia-N in Penaeus chinensis increased when shrimp were exposed to increased ambient ammonia$\mathrm{N}$. After $4 \mathrm{~h}$, the hemolymph ammonia- $\mathrm{N}$ level in shrimp exposed to $0.03 \mathrm{mg} \mathrm{l}^{-1}$ ambient ammonia-N was $2.69 \mathrm{mg} \mathrm{l}^{-1}$, whereas the hemolymph ammonia-N level in shrimp exposed to $10.11 \mathrm{mg} \mathrm{l}^{-1}$ ammonia-N was $6.97 \mathrm{mg} \mathrm{l}^{-1}$. The present study indicated that, during $24 \mathrm{~h}$ exposure to ammonia- $\mathrm{N}$ increased from 0 to $20 \mathrm{mg} \mathrm{l}^{-1}$ in $30 \%$, hemolymph ammonia rose from 328 to $1412 \mu \mathrm{mol} 1^{-1}$, hemolymph urea rose from 1492 to $2079 \mathrm{mmol} \mathrm{l}^{-1}$ with a concomitant decrease in ammonia-N excretion from 8 to $-18 \mu \mathrm{g} \mathrm{g}^{-1} \mathrm{~h}^{-1}$. There were concomitant increases in DON excretion from 2.2 to $61.4 \mu \mathrm{g} \mathrm{g}^{-1} \mathrm{~h}^{-1}$ and urea-N excretion from 0.2 to $23.2 \mu \mathrm{g} \mathrm{g}^{-1} \mathrm{~h}^{-1}$. This indicated that shrimp exposed to different concentrations of ammonia- $\mathrm{N}$ changed their excretory pattern.

It is noteworthy that high ambient ammonia caused shrimp to increase nitrite- $N$ excretion. Jensen (1990) reported that hemolymph nitrite of freshwater crayfish Astacus astacus exposed to $0.8 \mathrm{mmol} \mathrm{l}^{-1}$ nitrite reached 8 to $10 \mathrm{mmol} \mathrm{l}^{-1}$ within $2 \mathrm{~d}$. Chen \& Chen (1992) reported that the concentration of hemolymph nitrite-N of Penaeus monodon $(15.87 \pm 0.69 \mathrm{~g})$ was $0.140 \mu \mathrm{g} \mathrm{ml}^{-1}$. We propose that some of the ammonia entering the hemolymph may be converted to nitrite inside the animal, then coupled with hemocyanin and subsequently released under ammonia exposure.

The present study indicated that a small amount of nitrate- $\mathrm{N}$ was excreted by Penaeus monodon, and that nitrate- $N$ excretion seemed to increase with increased ambient ammonia-N. Nitrate-N excretion of $P$. monodon exposed to $5 \mathrm{mg} \mathrm{I}^{-1}$ ammonia- $\mathrm{N}$ in $20 \%$ was higher than when exposed to the same concentration of ammonia-N at 10 and 30\%. Spaargaren (1985) exposed Carcinus maenas to various salinity levels, 
and found that nitrate excretion was highest in brackish water and decreased at both higher and lower salinity levels. He suggested that nitrate formation may serve in the detoxication of ammonia and the maintenance of electroneutrality inside the crab.

Ammonia makes up 70 to $87 \%$ of total excreted nitrogen in marine amphipods (Dresel \& Moyle 1950), 60 to $100 \%$ in the copepods Calanus helgolandicus (Corner \& Newell 1967) and Tigriopus brevicornis (Harris 1973), $72 \%$ in spiny lobster Fasus edwardsi (Binns \& Peterson 1969), 86\% in Carcinus maenas (Needham 1957) and $95 \%$ in Atlantic ditch shrimp Palaemontes varians (Snow \& Williams 1971) and common shrimp Crangon crangon (Regnault 1983). Regnault (1987) reported that in decapod crustaceans, ammonia and amino acid accounted for 60 to 70 and $10 \%$ respectively of total nitrogen excreted. In the present study, ammonia- $\mathrm{N}$ accounted for $56.87,70.43$ and $78.13 \%$ of total nitrogen excreted by Penaeus monodon at 30,20 and $10 \%$, respectively. DON, which is considered to be mainly free amino acids, accounted for $22.18,2.58 \%$ and $4.40 \%$ of total nitrogen excreted by the shrimp at 30,20 and $10 \%$, respectively. However, when $P$. monodon was exposed to $5 \mathrm{mg} \mathrm{l}^{-1}$ ammonia-N at 30,20 and $10 \%$, ammonia- $N$ excretion was inhibited, and urea- $\mathrm{N}$ excretion and DON excretion increased to $20.92,11.44$ and $3.98 \%$ and to $65.28,72.05$ and $91.63 \%$ of total nitrogen, respectively. Our study reveals that the contribution of nitrogenous excretion in penaeids differs under various environmental conditions.

Hemolymph protein is reported for penaeids as 74 to $78 \mathrm{mg} \mathrm{ml}^{-1}$ in southern pink shrimp Penaeus duorarum (Bursey \& Lane 1971), $94 \mathrm{mg} \mathrm{ml}^{-1}$ in aloha prawn $P$. marginatus (Balazs et al. 1974), $103 \mathrm{mg} \mathrm{ml}^{-1}$ in $P$. chinensis (Chen et al. 1993) and 82, 112 and $112 \mathrm{mg} \mathrm{ml}^{-1}$ in P. monodon at 30,20 and 10\% (present study). The respiratory pigment hemocyanin accounts for 76 to $80 \%$ of hemolymph protein in $P$. japonicus (Chen \& Cheng 1993). Haberfield et al. (1975) observed an increase in the catabolism of amino acids that resulted in excretion of nitrogen, mainly as ammonia with decreased medium osmolarity. The fact that $P$. monodon exposed to ambient ammonia- $N$ greater than $20 \mathrm{mg} \mathrm{l}^{-1}$ had reduced hemocyanin and protein concentrations suggested an increase in catabolism of hemocyanin and protein to adjust osmoregulation. This physiological response affected the hemocyanin level more than the protein level. Hemocyanin played an important role in the catabolism of hemolymph protein of the penaeid under ammonia stress.

Tissue FAA of Penaeus japonicus was 546.81 and $1120.33 \mu \mathrm{mol} \mathrm{g}{ }^{-1}$ in 10 and $40 \%$ (Dalla Via 1986), and that of $P$. monodon was 185,320 and $365 \mu \mathrm{mol} \mathrm{g} \mathrm{g}^{-1}$ in 15, 30 and 45\%, respectively (Fang et al. 1992).
Hemolymph FAA was $3.32 \mu \mathrm{mol} \mathrm{ml}^{-1}$ in speckled shrimp, Metapenaeus monoceros (Rajulu \& Kulasekarapandian 1972), $5.80 \mu \mathrm{mol} \mathrm{ml} \mathrm{m}^{-1}$ in Homarus gammarus (Camien et al. 1951), 3.3, 6.3 and $2.8 \mu \mathrm{mol} \mathrm{ml} \mathrm{m}^{-1}$ in $P$. monodon in 15,30 and $45 \%$ (Fang et al. 1992), and $2.717,2.749$ and $2.541 \mu \mathrm{mol} \mathrm{ml} \mathrm{m}^{-1}$ in $P$. monodon in 10,20 and $30 \%$ (present study). An increase in the FAA and ammonia level, and a decrease of hemocyanin and protein in the hemolymph of shrimp exposed to ammonia- $\mathrm{N}$ at $5 \mathrm{mg} \mathrm{l}^{-1}$, explain the occurrence of further catabolism of amino acid to produce ammonia.

Chen \& Chen (unpubl.) found that the contribution of electrolytes in the hemolymph osmolarity decreased from 95.1 to $84.5 \%$ for Penaeus japonicus subjected to $20 \mathrm{mg}^{-1}$ ammonia-N. Despite the major part of hemolymph osmolarity of penaeid being regulated by inorganic ions (Fang et al. 1992), a significant increase of taurine in the present study implied that it was kept as osmolite. Taurine is well known to be strongly concentrated in the intracellular component, with a hemolymph concentration of $0.5 \mu \mathrm{mol} \mathrm{ml}^{-1}$ in a number of decapods (Charmantier et al. 1976). Taurine, which was $0.442,0.398$ and $0.429 \mu \mathrm{mol} \mathrm{m}{ }^{-1}$ in 10,20 and $30 \%$, increased to $0.689,0.530$ and $0.540 \mu \mathrm{mol}$ $\mathrm{ml}^{-1}$ at $20 \mathrm{mg} \mathrm{l}^{-1}$ ammonia-N in 10,20 and $30 \%$, respectively. The comparatively high levels of taurine and ammonia suggested that they played an important role in hemolymph osmoregulation of penaeids under ammonia stress.

Armstrong et al. (1978) demonstrated that ambient $\mathrm{NH}_{4}{ }^{+}$results in the inhibition of sodium absorption and an increase of $\mathrm{NH}_{4}{ }^{+}$uptake of giant freshwater prawn Macrobrachium rosenbergii. Young-Lai et al. (1991) reported that a decrease of hemolymph osmolarity in Homarus americanus following exposure to ammonia at $150 \mathrm{mg} \mathrm{l}^{-1}$ was caused by lower concentrations of sodium in the hemolymph. It is expected that the same responses may also exist in the hemolymph of Penaeus monodon when they are exposed to high ambient ammonia-N. Unfortunately, no determination was made for osmolarity and electrolytes in the hemolymph in the present study

Using Penaeus chinensis, Chen \& Nan (1992) documented that ammonia- $N$ excretion was inhibited and $\mathrm{Na}^{+}, \mathrm{K}^{+}$-ATPase activity decreased as shrimp were exposed to ambient ammonia- $\mathrm{N}$ at 10 and $20 \mathrm{mg} \mathrm{l}^{-1}$. In the present study, ambient ammonia- $\mathrm{N}$ at $5 \mathrm{mg} \mathrm{l}^{-1}$ caused an increase of hemolymph ammonia and urea, and decreases of hemocyanin and protein with a concomitant increase of free amino acids after 24 h exposure, suggesting that $P$. monodon exposed to ambient ammonia- $\mathrm{N}$ affects its nitrogen metabolism, and decomposes its hemocyanin and protein into free amino acids and urea to balance osmoregulation 
(Lasserre 1976). Accumulated ammonia- $\mathrm{N}$ in the hemolymph may also destroy the biosynthesis function of protein in hepatopancreas (Senkbeil \& Wriston 1981). Further research is needed to determine the electrolytes in hemolymph, and the enzyme activities involved in nitrogen metabolism of a penaeid under ammonia stress.

Acknowledgements. This is a partial result of the research work supported by the National Science Council of the Republic of China (project number NSC 82-0409-B019-007). The authors appreciate Dr Lars Hagerman, Marine Biological Laboratory, Helsingør, Denmark for his advice on the analysis of hemocyanin, and Dr T. K. Chiou, Department of Marine Food Science, NTOU, for his advice on analysis of free amino acid.

\section{LITERATURE CITED}

Antonini, E., Brunori, M. (1974). Transport of oxygen; respiratory protein. In: Hayashi, $O$. (ed.) Molecular oxygen in biology: topics in molecular oxygen research. Amsterdam, p. $219-274$

Armstrong, D. A., Chippendale, D., Knight, A. W., Colt, J. E. (1978). Interaction of ionized ammonia and un-ionized ammonia on short term survival and growth of prawn larvae, Macrobrachium rosenbergii. Biol. Bull. mar. biol. Lab. Woods Hole 154: 15-31

Balazs, G., Olbrich, S. E., Tumbleson, M. E. (1974). Serum constitutes of the Malaysian prawn (Macrobrachium rosenbergii) and pink shrimp (Penaeus marginatus). Aquaculture 3: 147-157

Bendschneider, K., Robinson, R. J. (1952). A new spectrometric method for the determination of nitrite in the sea water. J. mar. Res. 11: 87-96

Binns, R. (1969). The physiology of the antennal gland of Carcinus maenas (L.) V: some nitrogenous constituents in the blood and urine. J. exp. Biol. 51: 41-51

Binns, R., Peterson, A. J. (1969). Nitrogen excretion by the spiny lobster Fasus edwardsi (Hutton), the role of the antennal gland. Biol. Bull. mar. biol. Lab. Woods Hole 136: $147-153$

Boone, W. R., Schoffeniels, E. (1979). Hemocyanin synthesis during hypo-osmotic stress in the shore crab Carcinus maenas (L). Comp. Biochem. Physiol. 63B: 207-214

Bradford, M. M. (1976). A rapid and sensitive method for the quantitation of microgram quantities of protein using the principle of protein-dye binding. Analyt. Biochem. 72 : $248-254$

Bursey, C. R., Lane, C. E. (1971). Ionic and protein concentration changes during the molt cycle of Penaeus duorarum. Comp. Biochem. Physiol. 40A: 155-162

Camien, M. N., Sarlet, H., Duchateau, G., Florkin, M. (1951). Nonprotein amino acids in muscle and blood of some marine and freshwater crustacea. J. Biol Chem. 193 $881-885$

Campbell, J. W. (1973). Nitrogen excretion. In: Prosser, C. L. (ed.) Comparative animal physiology. W. B. Saunders Company, Philadelphia, p. 279-316

Charmantier, G., Charmantier, M., Voss-Foucart, M.-F., Jeuniaux, C. (1976). Les acides amines libres de l'hémolymphe des isopodes marins Sphaeroma hookeri, Sphaeroma serrtum (Flabellifera) et Idotea balthica (Valvifera). Arch. int. Biochem. 84: 989-996

Chen, J. C., Chen, S. F. (1992). Accumulation of nitrite in the haemolymph of Penaeus monodon exposed to ambient nitrite. Comp. Biochem. Physiol. 103C: $477-481$

Chen, J. C., Cheng, S. Y. (1993). Studies on haemocyanin and haemolymph protein levels of Penaeus japonicus based on sex, size and moulting cycle. Comp. Biochem. Physiol 106B: 293-296

Chen, J. C., Kou, Y Z. (1991). Accumulation of ammonia in the hemolymph of Penaeus japonicus exposed to ambient ammonia. Dis. aquat. Org. 11:187-191

Chen, J. C., Kou, Y Z. (1992). Effects of ammonia on growth and molting of Penaeus japonicus juveniles. Aquaculture 104: $249-260$

Chen, J. C., Lai, S. H. (1993). Effects of temperature and salinity on oxygen consumption and ammonia- $\mathrm{N}$ excretion of juvenile Penaeus japonicus Bate. J. exp. mar. Biol. Ecol. 165: $161-170$

Chen, J. C., Lin, C. Y. (1992). Oxygen consumption and ammonia-N excretion of Penaeus chinensis juveniles exposed to ambient ammonia at different salinity levels Comp. Biochem. Physiol. 102C: 287-291

Chen, J. C., Liu, P. C., Lei, S. C. (1990). Toxicities of ammonia and nitrite to Penaeus monodon adolescents. Aquaculture 89: $127-137$

Chen, J. C., Nan, F. H. (1992). Effect of ambient ammonia on ammonia- $\mathrm{N}$ excretion and ATPase activity of Penaeus chinensis. Aquat. Toxicol. 23: 1-10

Chen, J. C., Nan, F. H., Cheng, S. Y., Sheen, S. S. (1993). Effects of ambient ammonia on ammonia- $N$ and protein concentrations in hemolymph and ammonia- $\mathrm{N}$ excretion of Penaeus chinensis. Mar. Ecol. Prog. Ser. 98: 203-208

Claybrook, D. L. (1983). Nitrogen metabolism. In: Mantel, L. H. (ed.) The biology of Crustacea, Vol. 5, Internal anatomy and physioloical regulation. Academic Press, New York, p. 163-213

Corner, E. D. S., Newell, B. S. (1967). On the nutrition and metabolism of zooplankton IV. The forms of nitrogen excreted by Calanus. J. mar. biol. Ass. U.K. 47: 113-120

Dalla Via, G. J. (1986). Salinity responses of the juvenile penaeid shrimp Penaeus japonicus II. Free amino acids. Aquaculture 55: 307-316

Djangmah, J. S. (1970). The efects of feeding and starvation on copper in the blood and hepatopancreas and blood proteins of Crangon vulgaris (Fabricius). Comp. Biochem. Physiol. 32: 709-731

Dresel, E. I. B., Moyle, V. (1950). Nitrogenous excretion in amphipods. J. exp. Biol. 27: 210-225

Fang, L. S., Tang, C. K., Lee, D. L., Chen, I. M. (1992). Free amino acid composition in muscle and hemolymph of the prawn Penaeus monodon in different salinities. Nippon Suisan Gakk. 58: 1095-1102

Ferraris, R. P., Parado-Estepa, F. E., Ladja, J. M., De Jesus, E. G. (1986). Effect of salinity on the osmotic, chloride, total protein and calcium concentrations in the hemolymph of the prawn Penaeus monodon (Fabricius) Comp. Biochem. Physiol. 83A: 701-708

Gilles, R. (1977). Effects of osmotic stress on the protein concentration and pattern of Eriocheir sinensis blood. Comp. Biochem. Physiol. 56A: 109-114

Gilles, R., Pequeux, A. (1983). Interactions of chemical and osmotic regulation with the environment. In: Vernberg. F. J., Vernberg, W. B. (eds.) The biology of Crustacea. Vol. 8, Environmental adaptation. Academic Press, New York, p. 109-177

Haberfield, E. C., Haas, L., Hamman, C. S. (1975). Early ammonia release by a polychaete Nereis virens and a crab Carcinus maenas in diluted seawater. Comp. Biochem Physiol. 52A: 501-503 
Hagerman, L. (1983). Haemocyanin concentration of juvenile lobster (Homarus gammarus) in relation to moulting cycle and feeding conditions. Mar. Biol. 77: 11-17

Hagerman, L. (1986). Haemocyanin concentration in the shrimp Crangon crangon (L.) after exposure to moderate hypoxiá. Comp. Biochem. Physiol. 85A: 721-724

Hagerman, L., Baden, S. P. (1988). Nephrops norvegicus; field study of effects of oxygen deficiency on haemocyanin concentration. J. exp. mar. Biol. Ecol. 116: 135-142

Hagerman, L., Sondergaard, T., Weile, K., Hosie, D., Uglow, R. F. (1990). Aspects of blood physiology and ammonia excretion in Nephrops norvegicus under hypoxia. Comp. Biochem. Physiol. 97A: 51-55

Harris, R. P. (1973). Feeding, growth, reproduction and nitrogen utilization by the harpacticoid copepod Tigriopus brevicornis. J. mar. biol. Ass. U.K. 53: 785-800

Harris, R. R., Andrews, M. B. (1985) Total NPS pool and ammonia net efflux rate change in Carcinus maenas during acclimation to low environmental salinity. Comp. Biochem. Physiol. 82A: 301-308

Jensen, F. B. (1990). Sublethal physiological changes in freshwater crayfish, Astacus astacus, exposed to nitrite: haemolymph and muscle tissue electrolyte status, and haemolymph acid-base balance and gas transport. Aquat. Toxicol. 18: 51-60

Jeuniaux, C. (1971). Hemolymph-Arthropoda. In: Florkin, M. Scheer, B. J. (eds.) Chemical zoology, Vol. VI, Arthropoda, Part B. Academic Press, New York, p. 63-118

Kinne, O. (1976). Cultivation of marine organism: water quality management and technology. In: Kinne, O. (ed.) Marine ecology, Vol. III, Part 1. Wiley-Interscience, New York, p. 79-300

Kormanik, G. A., Cameron, J. N. (1981). Ammonia excretion in the sea-water blue crab (Callinectes sapidus) occurs by diffusion and not $\mathrm{Na}^{+} / \mathrm{NH}_{4}{ }^{+}$exchange. J. comp. Physiol. 141: $457-462$

Lasserre, P. (1976). Osmoregulatory response to estuarine conditions: chronic osmotic stress and composition. In: Lasserre, P. (ed.) Processes, Vol. 1, Uses, stress and adaptation to the estuary. Academic Press, New York, p. 395-413

Lei, C. H., Hsieh, L. Y., Chen, C. K. (1989). Effects of salinity on the oxygen consumption and ammonia- $\mathrm{N}$ excretion of young juveniles of the grass shrimp. Penaeus monodon Fabricius. Bull. Inst. Zool. Acad. Sin. 28: 245-256

Liao, I. C., Murai, T (1986). Effects of dissolved oxygen, temperature and salinity on the oxygen consumption of the grass shrimp, Penaeus monodon. In: Maclean, J. L., Dizon, L. B., Hosillos, L. V. (eds.) The first Asian fisheries forum. Asian Fisheries Society, Manila, p. 641-646

Mangum, C. M. Silverthorne, S. U., Harris, J. L., Towle, D. W., Krall, A. R. (1976). The relationship between blood $\mathrm{pH}$, ammonia excretion and adaptation to low salinity in the blue crab Callinectes sapidus. J. exp. Biol. 195: $129-136$

McCarthy, J. J. (1970). A urease method for urea in seawater. Limnol. Oceanogr. 15: 309-313

Needham, A. E. (1957). Factors affecting nitrogen excretion in Carcinus maenas (Pennant). Physiologia Comp. Oecol. 4: $209-239$

This article was submitted to the editor
Nickerson, K. W., Van Holde, K. E. (1971). A comparison of molluscan and arthropod hemocyanin. I. Circular dichroism and absorption spectra. Comp. Biochem. Physiol. 39B: $855-872$

Olson, K. R., Fromm, P. O. (1971). Excretion of urea by two teleosts exposed to different concentrations of ambient ammonia. Comp. Biochem. Physiol. 40A: 999-1007

Pequeux, A., Gilles, R. (1981). Na fluxes across isolated perfused gills of the chinese crab Eriocheir sinensis. J. exp. Biol. 92: 173-186

Pressley, T. A., Graves, J. S., Krall, A. R. (1981). Amiloridesensitive ammonium and sodium ion transport in the blue crab. Am. J. Physiol. 241: R370-R378

Quarmby, L. M. (1985). The influence of temperature and salinity on the nitrogen excretion of the spot prawn, Pandalus platyceros Brandt. J. exp. mar. Biol. Ecol. 87: $229-239$

Rajulu, G. S., Kulasekarapandian, S. (1972). A study of the free amino acids from the hemolymph of crustacea. Z. Zool. Syst. Evolutionsforsch. 10: 137-144

Regnault, M. (1983). Influence à long terme du taux protéique du régime sur l'excrétion d'azote et le métabolisme de la crevette Crangon crangon L. Océanis 9: 241-255

Regnault, M. (1987). Nitrogen excretion in marine and freshwater-water crustacea. Biol. Rev. 62: 1-24

SAS (1988). SAS/STAT user's guide, 6.03 edn. SAS Institution, Inc., Cary, NC

Senkbeil, E. G., Wriston, C. Jr (1981). Hemocyanin synthesis in the American lobster, Homarus americanus. Comp. Biochem. Physiol. 68 B: 163-171

Snow, N. B., Williams, P. L. LeB. (1971). A simple method to determine the $\mathrm{O}: \mathrm{N}$ ratio of small marine animals. J. mar. biol. Ass. U.K. 51. 105-109

Solorzano, L. (1969). Determination of ammonia in natural waters by the phenolhypochlorite method. Limnol. Oceanogr. 14: 799-801

Solorzano, L. Sharp, J. H. (1980). Determination of total dissolved nitrogen in natural waters. Limnol. Oceanogr. 25: $751-754$

Spaargaren, D. H. (1985). The significance of nitrate in the nitrogenous excretion of Carcinus maenas. Neth. J. Sea Res, 19: 119-124

Spaargaren, D. H., Richard, P., Ceccaldi, H. J. (1982). Excretion of nitrogen produts by Penaeus japonicus Bate in relation to environmental osmotic conditions. Comp. Biochem. Physiol. 72A: 673-678

Steel, R. G. D., Torrie, J. H. (1980). Principle and procedures of statistics. McGraw-Hill, Inc., New York

Wassenberg, T. J., Hill, B. J. (1984). Moulting behaviour of the tiger prawn Penaeus esculentus (Haswell). Aust. J. mar. Freshwat. Res. 35: 561-571

Wood, E. D., Armstrong, F. A., Richards, F. A. (1967). Determination of nitrate in sea water by cadmium-copper reduction to nitrite. J. mar. biol. Ass. U.K. 47: 23-31

Young-Lai, W. W., Charmantier-Daures, M., Charmantier, G. (1991). Effect of ammonia on survival and osmoregulation in different life stages of the lobster Homarus americanus. Mar. Biol. 110: 293-300

Manuscript first received: October 12, 1993

Revised version accepted: March 13, 1994 